\title{
Politics and the implementation of the New Poor Law: the Nottingham Workhouse controversy, 1834-43
}

\author{
JOHN BECKETT \\ University of Nottingham, UK
}

The Nottingham workhouse case was a test of the resolve both of the Poor Law Commissioners appointed to administer the post-1834 New Poor Law, and of the strength of the Whig interest in the town's municipal and parliamentary elections. All eyes were on the implementation of the legislation in Nottingham, partly because of the influential thinking of local administrators such as Absolem Barnett, and partly because the government needed evidence that the system of unions and workhouses set up after 1834 would actually work in industrial towns. The Nottingham case showed only too clearly that the key issue was the trade cycle, and fluctuations in the town's hosiery and lace trades made it almost impossible to implement the terms of the legislation fully. The key battle was fought over the decision to build a new workhouse, which the Whigs favoured and the Tories resisted.

KEYWORDS Nottingham, Poor Law, Barnett, poverty, workhouse, Tory, Whig, Guardians, politics, elections, less eligibility

In March 1842 Absolem Barnett, clerk and relieving officer to the Nottingham Poor Law Union, moved 140 paupers from the existing St Mary's parish workhouse into a new building on Mansfield Road. In itself this was hardly an unusual act. All across the country in the wake of the 1834 legislation new workhouses were built, and inmates transferred from older buildings which were either demolished or sold. In Nottingham the move was more symbolic; it was the final action in a long and bitter struggle rooted in political conflict over the implementation of the New Poor Law. When the Nottingham union was formed in 1836 its success or otherwise was regarded as a critical test for the new legislation, and initially it showed - give or take one or two rough passages - that the legislation could be successfully implemented. By the end of the $1830 \mathrm{~s}$ national attention had shifted towards the troublesome northern unions, where resistance to the legislation was more forthright. Public attention was distracted from the struggles which overtook the Nottingham union. Yet these were serious issues in relation to the implementation of the legislation in industrial towns more generally, and the opening of the new workhouse in 1842 was a symbolic 
but decisive triumph for supporters of the legislation, backed by the London-based Poor Law Commissioners.

The 1834 Poor Law Amendment Act became law on 14 August 1834. It revised the existing regulations on assistance to those in poverty and created a new administrative infrastructure, which included a three-man Poor Law Commission in London. The legislation was primarily designed to deal with the problem of rising costs, but it also introduced new principles for handling the poor. One of these was that able-bodied paupers should be relieved only in workhouses.

The task of the Poor Law Commissioners, together with their assistant commissioners in the field, was to implement the terms and conditions of the new law. These were largely derived from the findings of a Royal Commission which had examined the existing system of relief. One of the tasks of the assistant commissioners was to form unions under the control of boards of guardians, and they were then expected to guide the elected guardians in the direction of implementing new methods of relief. These included the gradual withdrawal of 'outdoor relief', in the form of payments in either cash or kind, for the able bodied. In place of such relief the poor were to be offered 'indoor relief' in a well-regulated workhouse. Initially the commissioners turned their attention to the southern counties where it was thought that the most notorious abuses of the old Poor Law had occurred; indeed, the problem of poverty in early nineteenth century England was seen primarily as a rural issue, and the New Poor Law came to be viewed as a reaction to the breakdown of the social cohesion of rural England.

The Royal Commission took the view that urban poverty was relatively well handled, and many MPs representing urban constituencies opposed the 1834 legislation on the grounds that it was designed to tackle a rural problem and was inappropriate for industrial towns. Since the Select Vestries Acts of 1817 and 1819, the administration of the old Poor Law had become relatively professionalised in towns. Many places had their own highly valued and effective systems of relief. ${ }^{1}$ Nottingham was no exception. Since 1819 the overseer of the

\footnotetext{
1 M.E. Rose, The Poor and the City: the English Poor Law in its Urban Context, 1834-1914 (Leicester, 1985), 3-6; M.E. Rose, 'The New Poor Law in an Industrial Area', in R. Hartwell, ed., The Industrial Revolution (Oxford, 1970), 122-3; M. Gorsky, 'Experiments in Poor Relief: Bristol 1816-1817', Local Historian, 25, 1 (1995), 17-30; T.
} 
poor in the parish of St Mary, Nottingham, had been Absolem Barnett, and he had developed practices much favoured by the Royal Commission; indeed, Barnett was a key witness before the commissioners because he had been advocating principles for handling the poor which came to be embodied in the legislation. 'Every parish', he wrote in a pamphlet published to coincide with the commission's enquiries, 'ought to have its poor house; but every poor house should be so ordered as to be a place irksome and abhorrent to every able-bodied pauper within its walls. ${ }^{2}$

Barnett's methods were not to everyone's taste in Nottingham, and the publication of his views was countered with a Tory-sponsored riposte written by T.H. Smith, an overseer of St Mary's and later treasurer of the Nottingham Union:

It is of the greatest importance to keep the number in the House as low as possible, not merely on account of the expense, although that is no trifling consideration, but chiefly because when the House is full, advantage is directly taken of that opportunity to make numerous applications for relief - the applicants knowing, that the Overseer has it not in his power to afford them accommodation in the workhouse, but must, if he relieve at all, give relief in money. ${ }^{3}$

Barnett may have set up a professional and well run poor law administration, but the political differences reflected in these pamphlets became critical to the implementation of the legislation after 1836. It was Barnett's rather than Smith's views which prevailed.

Workhouses had been built up and down the country for more than a century. Some were for individual parishes within towns, while in the countryside it was more common to find workhouses funded by groups of co-operating parishes. Each of the three Nottingham parishes had set up its own workhouse. The first, in St Mary's parish, was built on land between York Street and Mansfield Road in 1723. At much the same time St Nicholas's erected a workhouse on Gillyflower Hill. St Peter's initially used a building on Houndsgate,

May, The Victorian Workhouse (Princes Risborough, 1997); S. King and A. Tomkins, eds. The Poor in England, 1700-1850: an economy of makeshifts (Manchester, 2003)

2 A. Barnett, The Poor Laws and their Administration being an Enquiry into the Causes of English Pauperism and the Failure of Measures Intended for its Relief (Nottingham, 1833), 70

3 T.H. Smith, Hints to the Churchwardens, Overseers and Rate payers of Saint Mary's Parish, Nottingham partly designed to assist them in forming an opinion of the effects likely to result to their parish from the intended Alteration in the Poor Laws (Nottingham, 1834), 15 
and when that was demolished it took over a building in Broad Marsh. ${ }^{4}$ Under the terms of the 1834 legislation parishes were to be grouped into unions, each with its own workhouse.

To form the unions the Poor Law Commission in London sent assistant commissioners around the country to inspect existing arrangements and propose a course of action. Once a union was agreed, boards of guardians were elected consisting of representatives of each parish in the union. The guardians were tasked to employ staff and oversee the implementation and operation of the law.

The assistant commissioners expected the guardians to consider workhouse provision within the union, and from the beginning this was a cause of controversy. The Royal Commission had advocated deterrent workhouses, without going into detail. It had not envisaged unions having a single building; indeed, at least four were suggested: for the elderly, for children, and for male and female able-bodied poor. No advantage was perceived in bringing these different groups into the same accommodation, and if anything this was discouraged on the grounds that existing parish workhouses could be used for the different categories, thereby saving on capital costs. This explains the proposal in Leicester to utilize the existing parish workhouses: the assistant commissioner's made it clear that their aim was to bring the Union 'into efficient operation, by means of such Workhouses only as will find ready built'. ${ }^{5}$

The Poor Law Commissioners soon abandoned this laisse faire position and began instead to press guardians into agreeing to build new workhouses to accommodate all paupers, while retaining separation between the different ages and sexes. ${ }^{6}$ It was these views which prevailed by the time assistant commissioners reached the East Midlands in 1836 to set about the task of forming unions. In Leicester, the first board of guardians was elected in July 1836, and within a couple of months it had agreed to fund a 600-place workhouse to replace smaller, pre-1834 workhouses. Disputes among the guardians delayed a

\footnotetext{
4 P. Higginbotham, Workhouses of the Midlands (Stroud, 2007), 21; John Beckett, ed., A Centenary History of Nottingham (Manchester, 1997), 208-11

5 K. Thompson, 'The Building of the Leicester Union Workhouse, 1836-1839', in D. Williams, ed., The Adaptation of Change (Leicester, 1980), 59-60

6 M.A. Crowther, The Workhouse System 1834-1929 (London, 1981), 37-44; Kathryn Morrison, The Workhouse: a study of Poor Law Buildings in England (Swindon, 1999); Charlotte Newman, 'To punish or protect: the New Poor Law and the English workhouse', International Journal of Historical Archaeology, 18 (2014), 122-45
} 
final decision and work started only in 1838, with completion in 1839. ${ }^{7} \mathrm{~A}$ new workhouse was also built in Derby, ${ }^{8}$ but it was the Nottingham union in which events were watched most closely: in the words of Edward Gulson, the assistant commissioner responsible for setting up the Nottingham union, it was 'the first union so strictly manufacturing that has been effected'. ${ }^{9}$ Nottingham was sufficiently important as a precedent for future union formation in northern England that the implementation of the legislation was discussed in detail in the Poor Law Commissioners' third annual report. ${ }^{10}$

The Nottingham union quickly came to be regarded as a beacon. Edward Gulson, the assistant commissioner, reported only weeks after the formation of the union that the guardians were carrying out 'your wishes both in spirit and letter more rapidly and cordially than any other Board of Guardians I ever saw'. ${ }^{11}$ Absolem Barnett, clerk, relieving officer and workhouse master, had practised a form of less eligibility prior to 1834 , in which conditions in the workhouse were to be worse than anything comparable outside. Consequently, for the Poor Law Commissioners in London, having Barnett running the Nottingham union was a distinct advantage. It was clear that he would be in favour of the legislation, and it was primarily through his efforts that one of the critical principles of the new legislation - less eligibility - was put into practice.

What soon became apparent was that the implementation of the New Poor Law would be politically divisive. The bill had run into little difficulty in Parliament. Since a major outcome of the legislation was expected to be a reduction the payment of poor relief, and by implication therefore also in the poor rates, both parties had a vested interest in seeing it succeed. It was passed by a Whig administration, but most Tories were happy to support the proposals and, perhaps as a result, the bill passed with little detailed discussion. However, when it came to the reality of making the new legislation work, this consensus broke down, perhaps nowhere more so than in Nottingham. Although the Nottingham case has often been quoted by historians, ${ }^{12}$ the fullest account of the formation of the union and the struggle to build the workhouse was published

\footnotetext{
7 Thompson, 'Leicester Union Workhouse', 59-76

8 J. Lindsay, "'Excellent Order Throughout": Derby Workhouse 1834-44', Derbyshire Archaeological Journal 100 (1980), 26; G.T. Styles et al., 'The Formation of the Derby Poor Law Union', Derbyshire Miscellany, 6 (1971-3), $55-67$

9 The National Archives (TNA) MH12/9444, E. Gulson to J.G.F. Lefevre, 26 Sept 1836

10 Third Annual Report of the Poor Law Commissioners, 1837, (BPP 1837 (546-1), XXXI, p. 7). There were further references in the 4th and 8th reports.

11 TNA MH12/9444, Gulson to the Poor Law Commissioners (PLC), 24 July 1836

12 For example, Crowther, Workhouse System, 47
} 
fifty years ago by Roy Church. ${ }^{13} \mathrm{He}$ relied heavily on reports in the Nottingham Review, a radical Whig newspaper edited by Richard Sutton. For his part, Sutton was a relatively hard-line supporter of the 1834 legislation who nevertheless resisted the idea of building a new workhouse. Church did not use the Tory Nottingham Journal, edited in these years by John Hicklin, who spearheaded the opposition to the full implementation of the legislation in Nottingham, and nor did he use the Poor Law Commissioners papers. ${ }^{14} T$ These include correspondence with Barnett, and the regular reports on the Nottingham union supplied by assistant poor law commissioners. A later account of the new Poor Law by Maurice Caplan, made some use of the commissioners papers, but his discussion of the Nottingham union was relatively brief and made only passing reference to the political issues which underlay the workhouse debate. ${ }^{15}$ The building of the new Nottingham workhouse highlighted some of the core political problems which arose in conjunction with the new Poor Law, and sheds particular light on the problems of implementation in a union which was considered to be a flagship for the new legislation.

Edward Gulson, the assistant commissioner responsible for Nottinghamshire, was already well experienced in his trade by the time he arrived in the county town in 1836. Forming the Worksop, Mansfield and East Retford unions caused him few problems, but the south of the county was more of a challenge. Gulson proposed to separate out the parishes of Lenton, Radford and Sneinton, part of the pre-1834 Basford Incorporation, to create a single union, and to unite the three Nottingham parishes into a union of their own. It was not an easy decision. His reason for separating off Lenton, Radford and Sneinton, which surrounded Nottingham on three sides, was taken on the basis of present and predicted population figures: 'I think it will be much more safe to make them a separate Union, than by bringing them to Nottingham create so large a union as might in case of a depression in the trade cause some difficulty

\footnotetext{
13 R.A. Church, Economic and Social Change in a Midland Town, Victorian Nottingham 1815-1914 (London, 1966), 112-21

14 TNA, MH12 is one of a series of categories among the Ministry of Health papers originally relating to Poor Law matters. It is by far the largest group with 16,741 volumes of correspondence covering the period 1834-1900. The material is particularly useful for the Nottingham Union for which there are no Union records surviving before the 1850s: K.M. Thompson, 'Sources for the New Poor Law in the Public Records', Journal of Regional and Local Studies, 7 (1987), 1-13

15 Maurice Caplan, In the Shadow of the Workhouse (Nottingham, 1984), 21-5; Derek Fraser, Urban Politics in Victorian England (Leicester, 1976), 76-8, provides a short account derived from newspaper evidence.
} 
in dealing with so considerable a mass of population at one focus'. ${ }^{16}$

There was a further, unspoken, consideration which also drove Gulson's recommendation. He was anxious to recognize Barnett's contribution to the formulation of the 1834 legislation, and in forming two separate Unions for Radford (with Lenton and Sneinton) and Nottingham, he was undoubtedly taking Barnett's advice. Similarly, he accepted Barnett's views in regard to workhouse accommodation. Barnett reported that the average number of inmates was 360 , and there were 387 inmates during one week in the summer of $1834 .{ }^{17}$ The average over the previous decade or so had been between 300 and 400 falling to only 227 in $1835-6 .{ }^{18} \mathrm{Gulson}$ argued that on these figures the existing workhouse in St Mary's parish would provide 'ample workhouse accommodation' for the town. ${ }^{19}$ And because of Barnett's 'sound principles of administration' over previous years it was already divided along the lines favoured by the Poor Law Commissioners, separating children from adults and so on. ${ }^{20}$ As William Roworth, a political opponent of Barnett, noted rather acidly in 1840 'I consider the removal of the poor out of the three workhouses into one, with other circumstances connected with the same, as a mere pretext to carry out the working of the new poor law'. ${ }^{21}$

Gulson's faith in Barnett was amply rewarded once the Nottingham union was set up. ${ }^{22}$ The first election of guardians was held in July 1836. The board was to consist of 24 members, or whom twelve were elected representatives of St Mary's - by far the largest of Nottingham's three parishes - and the two smaller parishes of St Nicholas's St. Peter's had six representatives each. Sixteen nominations were received from St Mary's, and the four unsuccessful candidates were all Tories. It was a quiet election with the existing overseers of the three parishes all elected to the new board of guardians. Gulson attended the first meeting on 14 July when Barnett was appointed clerk to the union, master of the

\footnotetext{
16 TNA MH12/9333, Edward Gulson to the PLC, 3 June 1836. The two unions were subsequently combined following a borough extension in 1877.

17 Report from Her Majesty's Commissioners for Enquiring into the Administration and Practical Operation of the Poor Laws 1834 (BPP XXVII (44), pp. 890-3, appendix A pp. 111a-112a, appendix B, part v.

18 The figures differ somewhat. These figures are taken from a report of 1842: TNA MH12/9446, John Brewster to the PLC, 1 February 1842. William Felkin's average for 1836, a prosperous year and the one during which Gulson formed the Union, was 350, with a further 700 on outrelief: W. Felkin, 'Statistics of the Labouring Classes and Paupers in Nottingham', Journal of the Statistical Society, II (1839), 457-9.

19 TNA MH12/9444, Gulson to Edwin Chadwick, 11 June 1836.

20 TNA MH12/9333, Gulson to the PLC, 3 June 1836.

21 W. Roworth, Observations on the Administration of the New Poor Law in Nottingham (Nottingham, 1840 ), 6.

22 James Orange, History of Nottingham (Nottingham, 1840), 904, gives a full account of life in the workhouse.
} 
workhouse, and relieving officer, at a salary of $£ 250 .{ }^{23} \mathrm{His}$ unmarried daughter became the matron. ${ }^{24}$ It was a substantial salary, but Gulson believed it to be fully justified:

knowing Barnett as you doubtless do, by character, and considering that he had $\mathrm{f} 200$ for St Mary's alone, I hope you will not think it too much. The advance I have advocated both because I think his services are well worth the money, because his work will be increased from the addition of the two parishes, and because he has done more to effect the quiet introduction of the measure into Nottingham than any body of men could by themselves have effected, his services are in fact invaluable, and he is very grateful for the advance. ${ }^{25}$

The guardians agreed that outdoor relief should be refused to able bodied males 'to make the administration of relief to the poor conform to the practice already established in the parish of St Mary ... in which, for three years previous to the formation of the Union, no relief had been given to able-bodied males excepting the workhouse'. ${ }^{26}$ This prohibition was accepted in Nottingham rather earlier than in many other unions - no doubt reflecting Barnett's influence. The guardians also accepted Gulson's recommendation that they should close the two smaller workhouses in the parishes of St Nicholas's and St Peters' and transfer their 54 inmates to St Mary's. ${ }^{27}$

The Poor Law Commissioners could not have hoped for much more. A Whig-leaning board of guardians had effectively endorsed Barnett's personal crusade, and given him the opportunity to lead the implementation of the new legislation. As Roworth later noted, the decision to invest Barnett with a virtual monopoly of the offices connected with poor relief seemed to be nothing short of an inducement to him 'to be the active and principal agent, in furthering the plans of the commissioners to carry out their design'. ${ }^{28}$ Barnett did not let them down. He was 'much looked up to' and 'the Nottingham Union works capitally, and they carry out your wishes both in spirit and in letter more rapidly and cordially than any Board of Guardians I ever saw. They have in fact already made

\footnotetext{
${ }^{23}$ It was highly unusual for one person to hold all three offices, and this gave Barnett enormous influence. He resigned as master of the workhouse only in 1845: Nottingham Review (NR) 18 April 1845

24 NR 15 July 1836

25 TNA MH12/9444, Gulson to the PLC, 24 July 1836

26 Third Annual Report of the Poor Law Commissioners, 7

27 NR 29 July 1836

28 Roworth, Observations, 6
} 
all necessary amendments and alterations. ${ }^{129}$ This was Gulson's view, and he had, of course, backed Barnett believing that he would remain resolute should the guardians waver, as they often did in other places. Unfortunately Barnett, Gulson and the Poor Law Commissioners had made one error of judgement - the workhouse was not large enough.

III

For the New Poor Law to work in all its essentials, it was critical to have available sufficient workhouse accommodation to house able-bodied males who applied for relief. The St Mary's workhouse, to which all the workhouse residents were transferred in 1836, was built in $1780 .{ }^{30}$ Situated on York Street, north of the town centre, it was described in 1795 as dark, verminous, ill-ventilated, and utterly inadequate accommodation for the 168 inmates. ${ }^{31}$ By 1808 it was in such a poor state that the St Mary's Vestry negotiated with the corporation for a much larger site on which to build a new workhouse. In the event the Vestry voted to try to save expense by repairing and extending the existing building at a cost of $f 5,000 .{ }^{32}$ It was not a great success, and the house was described in 1840 as 'very uncomfortable, and not so much like a workhouse as a prison'. ${ }^{33}$ But unappealing as the condition of the workhouse may have been, it was size rather than comfort which became the critical issue.

Barnett was aware that the pressure on space in the St Mary's workhouse could be considerable. During a downturn in trade in 1816 the number of paupers crowded into the workhouse had reached 505, even though the maximum number it was supposed to hold was $500 .{ }^{34}$ Since then the population of the town had grown considerably, but the available figures showed that the number of inmates had remained well below the maximum. It helped Barnett's case, of course, to be able to claim that when the principles of the New Poor Law were enforced the destitute stayed away from the workhouse and numbers remained well within the capacity of the existing building. However, the figures came mainly from the twist-net fever years as Nottingham prospered in the 1820s from its booming lace industry. By contrast, Barnett had to implement the

\footnotetext{
29 TNA MH12/9444,Gulson to the PLC, 24 July 1836

30 Nottinghamshire Archives (NAO), DD.TS/15/2/2 Vestry Minutes, St Mary's.

31 F. Eden, The State of the Poor (1797), II, 573; J.D. Chambers, Nottinghamshire in the Eighteenth Century (2nd edn., London, 1966), 237-42

32 J. Blackner, The History of Nottingham (Nottingham, 1815), 69-70

33 J. Orange, History and Antiquities of Nottingham (Nottingham, 1840), II, 904

34 William Stretton, The Stretton Manuscripts (Nottingham, 1910), 175
} 
New Poor Law in the context of trade depressions connected with more general economic conditions in the later 1830s and early 1840s. In these circumstances the St Mary's workhouse proved inadequate.

Un- or under-employment was a major cause of economic insecurity for British industrial workers during the nineteenth century. Business-cycle downturns occurred roughly every five to eight years. Nottingham's staple hosiery and lace trades were particularly vulnerable to periods of cyclical unemployment, and the first test of the guardians' resolve came in the general recession of 1836-8 when both trades were affected. The downturn began in 1836, and by mid-January 1837 the workhouse had 500 inmates and was full. What was to be done? Gulson told the Poor Law Commissioners that in his view the guardians would have either to acquire additional accommodation, or 'to apply to the Board of Poor Law Commissioners for some temporary relaxation of the Rule forbidding outdoor relief to the able bodied during the time of emergency'. He went on to assure the commissioners that the great majority [of guardians] have felt that thus early to relax a rule, acknowledged to be good, would be an evil of magnitude, and therefore to be avoided, if by any means possible.' Consequently 'the Guardians resolved to add to the Workhouse accommodation by gaining possession of some parish houses adjoining the premises. This was accomplished last week. The additional space thus secured is intended for the children now in other parts of the house. ${ }^{135}$ By removing 200 children, plenty of space would be created for additional adults. ${ }^{36}$

The politics of this debate were obvious. Supporters of the new legislation, including Barnett, Gulson, and the guardians wanted to see it fully implemented even - perhaps particularly - in testing economic times, but since the basic principle revolved around admission to the workhouse it was critical to have sufficient space to accommodate those in need. Opponents preferred the older principle of providing outdoor relief through what were accepted as temporary periods of difficulty. Barnett admitted early in February 1837 that the number of inmates, ' 495 last week and 484 this week is too great to admit of desirable management'. ${ }^{37}$ By March 1837, Gulson was forced to accept that pressure on space was no longer tolerable. ${ }^{38}$ The union's medical officers criticised the

\footnotetext{
35 TNA MH12/9444, Gulson to PLC, c.26 Jan 1837

36 TNA MH12/9444, T.H. Smith to PLC, 14 Jan 1837

37 TNA MH12/9444, Barnett to PLC, 4 Feb 1837. Barnett's realistic assessment was in marked contrast to Gulson's upbeat report sent the previous day: MH12/9444, Gulson to PLC, 3 Feb 1837

38 TNA MH12/9444, Gulson to PLC, 18 March 1837
} 
overcrowding among children, with up to six sharing a single bed - they thought four was the maximum that should be tolerated..$^{39}$ Gulson finally admitted that he and Barnett had made a mistake in not pressing for a new and larger workhouse when the union was formed. ${ }^{40}$

Unfortunately for Barnett and his supporters it was in the middle of these debates that the board of guardians came up for re-election in late March 1837. By contrast with the first contest in July 1836 this was a much livelier affair. Of the twenty-four guardians elected only five (including local businessman and social reformer William Felkin) had served before. Twenty-five candidates stood for the twelve seats in St Mary's, of whom eleven were nominated by Rev. W.J. Butler, and formed the 'select Tory list'. Four of the eleven were elected. Dr George Wilkins, vicar of St Mary's, was also elected, together with John Hicklin and Richard Sutton, proprietors of the Tory Nottingham Journal and the Radical Nottingham Review. Thomas Wakefield, leader of the Whigs on the reformed Corporation, and first post-1835 mayor, was elected chairman. ${ }^{41}$

The insufficiency of accommodation within the workhouse was vigorously debated during the contest. Those supporting the Tory line of thinking saw this as an opportunity to vitiate the full effects of the 1834 legislation by proposing the resumption of outdoor relief to the able-bodied while the depression lasted. It was on this political ticket that they fought the election, and although the Whigs were returned with a small majority Barnett recognized that he was in difficulty. With 600 people crammed into workhouse accommodation he was convinced that without more space he could not hope to uphold the key principles:

There is no doubt whatever of the absolute necessity of procuring Workhouse room to a greater extent than is at present provided. I have impressed this upon the Guardians constantly and as you are aware they have already extended their means considerably (for 100). The greatest difficulty exists in procuring any place for the purpose, to obtain any further accommodation near the present house is totally impossible, but I hope to be able to obtain another place to which a class, say the old - or the young - may be removed.

\footnotetext{
39 NR 17 March 1837

40 TNA MH12/9444, Gulson to PLC, 18 March 1837

41 NR 31 March, 7 April 1837
} 
He was undoubtedly right, but the new board 'many of them decided opponents of the system, and chosen on that ground' was less likely to give him unqualified support. ${ }^{42}$

The new board of guardians voted to re-open the old St Nicholas' workhouse as a hospital and dispensary. ${ }^{43}$ More significantly, the guardians resolved 'that in the present state of trade in Nottingham it is inexpedient and impracticable to carry out the full regulations of the Poor law as to outdoor relief'. They recommended that 'the relieving officer be instructed to give relief to able bodied men during the present pressure in such urgent cases as on due enquiry shall appear to require immediate relief'. ${ }^{44}$ Outdoor relief, in other words, was to be reintroduced.

The logic of the guardians' position was quite simple. The town had insufficient workhouse accommodation to meet the demand during the recession in trade, and rather than crowding paupers into inadequate accommodation it made sense to relieve them in their own homes until the emergency was over. The Poor Law Commissioners would have accepted such an expedient, but Barnett was unwilling to submit without a fight, and as an alternative he proposed a work scheme:

The plan is this. Some sewers are about to be made in a new part of the town, and a large portion of digging is required, both for clay and for other measures ... Nottingham artisans are to be employed.... If therefore a man with a large family applies for relief, whom Mr Barnett knows to be industrious who is not of pauper habits, but by the depression of trade is thrown out of employ, and obliged to seek temporary assistance from the Parish, Barnett is deputed by the Managers of the private subscription to acquaint such a man, that he will endeavour to procure him some employment, and ordering him to call at a certain time of the day, when no other paupers are present, he gives him an order to the Foreman of the work in hand, who sets him on by task work at such price as would enable him to earn a scanty pittance. Any applicant of pauper habits, or of other description than the extreme case described above, is offered indoor relief. ${ }^{45}$

\footnotetext{
42 TNA MH12/9444, Barnett to PLC, 7 April 1837

43 NR 14 April 1837; TNA MH12/9444, Gulson to PLC, 19 April 1837

44 NR 31 March, 15 May 1837; TNA MH12/9444, Barnett to PLC, 15 April 1837

45 TNA MH12/9444, Gulson to PLC, 23 April 1837; Barnett to PLC, 27 April 1837; NR 28 April 1837
} 
The provision of work for unemployed men was not uncommon and, as in this case, the emphasis was on 'private subscription' rather than the poor rate. ${ }^{46}$ The initiative had come from Richard Morley, a leading Whig hosiery manufacturer, and current mayor of Nottingham, who called a public meeting and formed a relief committee. By 5 May over $f 1500$ had been promised for the sewers project, but at this point Barnett found himself at cross purposes with the guardians. Gulson had already informed the chairman of 'the willingness of the commissioners to sanction such departure from the present rule, as the emergency of the case, and the necessity of the times, might render expedient'. With this assurance, the guardians promptly voted to suspend the prohibition of outdoor relief. ${ }^{47}$ Barnett was not amused: 'my decided opinion is that the purpose of the resolution is to injure the subscription and if possible compel a departure from the principle of the Bill'. At the same time he recognized the weakness of his position: 'but for the subscription we could not by any means have avoided outdoor relief to a considerable extent to able bodied poor. ${ }^{148}$ There were at that point 639 people in workhouse accommodation.

The charitable subscription launched by Morley had raised $\mathrm{f3,142} 17 \mathrm{~s}$ by 12 May 1837, and 733 men had been put to work. ${ }^{49} \mathrm{~A}$ week later more than 1000 men were at work, and the numbers continued at this level through June as the depression showed no sign of abating. By mid-July Barnett was again concerned: 'I have reason to apprehend that in two or three weeks if not earlier the workhouse will be perfectly filled.' The Relief Fund was running out of money, and numbers employed fell from over 1000 to 128 on 19 August, with a consequential knock-on effect on demand for the workhouse. Barnett had few options left: the prevailing conditions 'will render necessary an extension of outdoor relief'. ${ }^{50}$ He also proposed an outdoor labour test. ${ }^{51}$

The Poor Law Commissioners had seen the outdoor labour test as a potential interim stage in the introduction of the full rigours of the new legislation, whereby able-bodied paupers were enabled to do hard labour in

\footnotetext{
46 George R. Boyer, 'The Evolution of Unemployment Relief in Great Britain', Journal of Interdisciplinary History 34/3 (2004), 393-433

47 TNA MH12/9444, Gulson to PLC, 23 April 1837; NR 12 May 1837

48 TNA MH12/9444, Barnett to PLC, 27 April 1837, 7 May 1837

49 NR 12 May 1837

50 THA MH12/9444, Barnett to PLC, 15 July 1837

51 He may well have discussed this with Gulson who, in a report to the Poor Law Commission completed around this time suggested that the outdoor labour test ought to be invoked 'only in extreme or emergency cases': 3rd Annual Report of the Board of Poor Law Commissioners, 1837 (BPP 546-1), XXXI, 7-9
} 
return for relief. It was a principle employed by Barnett on several occasions under the old Poor Law, and advocated by him to the Royal Commission. ${ }^{52} \mathrm{His}$ opponents had other ideas: 'the cruelty of employing frame-work knitters upon such works ought to deter any overseer from resorting to it. The stockinger in general is delicate, badly clothed and badly fed; altogether unfitted for the hardships arising out of a situation so opposite to his usual mode of life. ${ }^{153}$ Barnett proposed that able bodied men with families should be offered work digging and moving soil for the course of a road across Mapperley Common. For this they would be offered poor relief, two-thirds of which would be paid in money, and the other one-third in food substitutes, bread and potatoes, which would be delivered to the men's families twice a week. More than one hundred men were put to work. ${ }^{54}$

The labour test alleviated the problem temporarily. By mid-October 1837 there were 750 people in workhouse accommodation and additional rooms were being prepared in a large building in the grounds of the old St Nicholas' workhouse. This was thought sufficient to accommodate thirty or forty more paupers, and a further expedient involved building a wooden hut next to the workhouse in which 200 or so people could be fed each day without needing to be brought into the existing accommodation. ${ }^{55}$ This all took time, and by mid-November, with 866 in the workhouse and 177 men employed on work relief, Barnett was close to recognising that the situation was still too serious to be tackled through short-term expedients: 'it may be feared we must go on to give out door relief in food etc., to those whom if we had the house or other test to offer we should refuse'. ${ }^{56} \mathrm{By}$ the end of the month there were 947 people in workhouse accommodation, 208 men employed on road construction, and more than 208 being fed daily in the temporary hut, on milk porridge and bread at 10 a.m. and meat and vegetable soup at 2.p.m. ${ }^{57}$

The cyclical nature of the trade cycle ensured that recovery would eventually take place, and in mid-December Barnett reported 'a very decided improvement in the hosiery trade and indications of a revival in the lace trade'. On 27 December he ended the system of providing meals, and although numbers

\footnotetext{
52 Barnett, Poor Laws, 6

53 Smith, Hints to the Churchwardens, 13

54 NR 8 September 1837; TNA MH12/9444, Barnett to PLC, 18 August 1837, and their reply 21 August 1837; Beckett, ed., Centenary History, 232

55 TNA MH12/9444, Gulson to George Nicholls, 1 Nov 1837; Barnett to PLC, 9 Nov 1837

56 TNA MH12/9444, Barnett to PLC, 11 Nov 1837

57 TNA MH12/9444, Barnett to PLC, 25 Nov 1837
} 
in accommodation fluctuated through January and February 1838 they gradually trended downwards. ${ }^{58}$ They settled around 420 by midsummer. Sir George Nicholls, one of the Poor Law Commissioners, and an overseer of the Southwell workhouse before 1834, was able, give or take a few glosses of the facts, to claim that Nottingham's experience in these months was a ringing endorsement of the legislation: 'the guardians had the satisfaction of seeing a natural state of things restored, without having been driven to violate principle or yield to clamour'. ${ }^{59}$

The depression of 1836-8 had highlighted the question of workhouse accommodation. If numbers on relief were going to continue at the levels reached in 1837 either a new workhouse was needed or the principles of the legislation would have to be breached and outdoor relief given. Barnett was in no doubt which solution he favoured. In August 1837 he was delighted to note a growing 'conviction' on the part of the guardians 'that a new and larger workhouse is indispensable.' However, he added that 'it may be doubted whether there is sufficient moral courage to encounter the unpopularity which must be consequent upon the attempt.' The Nottingham Review, a consistent supporter of the new Poor Law, reported that 'a feeling was manifested in favour of erecting a new workhouse'. ${ }^{60}$

In November 1837 a report drawn up by five visiting guardians (including William Felkin) recommended the building of a new workhouse of an adequate size. In their view the cost of additional accommodation, the likelihood that the depression would be succeeded by another, and the difficulties of enforcing the workhouse regulations in the overcrowded conditions, meant that there was no practical alternative. ${ }^{61}$ Quite how stretched the position had become was summarized in a report drawn up by Edward Gulson:

The original capacity of the Workhouse was for 500 persons, it was first enlarged so as to contain 600 then 700 and lastly 800 . On the 4th of November 804 were within the walls, and a still greater addition to that accommodation ... became absolutely necessary. Some carpenters sheds

\footnotetext{
58 TNA MH12/9444, Barnett to PLC, 16, 29 Dec 1837, 6 Jan 1838, 24 March 1838, 7 April, 30 April 1838

59 Sir George Nicholls, A History of the English Poor Law (new edn., London, 1898), II, 328-31. For the pre-1834 Nottinghamshire reformers and their work see J.D. Marshall, 'The Nottinghamshire Reformers and their Contribution to the New Poor Law', Economic History Review, XIII (1961), 382-96

60 TNA MH12/9444, Barnett to PLC, 12 August 1837; NR 18 August 1837

61 TNA MH12/9444, Report of 7 Nov 1837; NR 10 Nov 1837
} 
adjoining the workhouse have therefore been procured, these are now fitted up as sleeping rooms, so as to provide for 50 or 60 more cases.... Since this was written the increase of pressure has been such, as to induce the Board of Guardians still further to enlarge their means of providing for the ensuing winter. The workhouse accommodation has this week been extended so as to contain 900 inmates ( 866 are already admitted). ${ }^{62}$

What is striking about these comments is the makeshift nature of the arrangements in pursuit of the principle of less eligibility, but the guardians remained divided on the question of a new workhouse. There were plenty of arguments in favour. A new workhouse would permit proper separation of the sexes and families, as required by the 1834 legislation but impossible to impose in the chaotic current conditions. ${ }^{63}$ It would also ensure that in-relief could be offered to all able bodied applicants in all but the most depressed conditions. A new workhouse might also be a sensible investment in view of the maintenance costs of the existing workhouse properties. Against these perfectly reasonable arguments opponents argued that larger premises would enable the Poor Law Commissioners to insist on the most stringent regulations including the separation of families and the enforcement in all circumstances of the workhouse test. A third position was that taken by Richard Sutton, proprietor of the Nottingham Review, who supported the principles behind the 1834 legislation but opposed the spending of public funds on a new workhouse preferring to give the guardians discretion in applying the labour test during periods of distress. Given these varying viewpoints a sub-committee was set up to try to decide what to do. ${ }^{64}$

The committee reported at the end of March 1838, just at the point where the depression was lifting and numbers in the workhouse were falling. It recommended building a new workhouse, at an estimated cost of $£ 9,000$ in addition to the land. No further discussion took place until a new board of guardians had been elected. With the return of better conditions it is hardly surprising that when they met in June, the guardians threw out the recommendation. Gulson, putting a brave face on the matter, pointed out that the union at least had additional accommodation should conditions again

\footnotetext{
62 TNA MH12/9444, Gulson's report 20 Nov 1837

63 Facts and Observations Submitted to the Candid Consideration of the Rate-Payers of Nottingham in Reference to the Election of Guardians, by an Old Inhabitant (Nottingham, 1839), 4

64 NR 10, 24 November 1837, 3 March 1838; TNA MH12/9444, Barnett to PLC, 23, 30 Nov 1837; NR 1, 29 Dec 1837
} 
deteriorate. $^{65}$

The guardians may have hoped that this was the end of the matter, but if so they were mistaken. Gulson was replaced as assistant commissioner for Nottinghamshire by Richard Hall in the autumn of 1838 , and he was quick to point out that the available accommodation was 'very bad, quite inadequate to its requirements, and will hardly admit of an attempt at classification'. ${ }^{66}$ The guardians recognised that they had an ongoing problem even if the downturn in the textile trades had passed. Plans and estimates for a new workhouse to accommodate 1000 people were discussed at a special meeting in January 1839, and it was agreed to call a town meeting at which views could be aired on the issue. Opponents circulated handbills headed 'New Bastille' around the town, while the guardians invited ratepayers to inspect the existing workhouse to see for themselves the inadequate conditions in which the inmates lived. ${ }^{67}$

The town meeting was held in the closing days of January 1839 and produced a heated debate partly inflamed by Richard Sutton's suggestion in the Review that the likely cost would be in the region of $£ 20,000 .{ }^{68}$ On 7 February the guardians agreed to continue planning for a new workhouse, although Barnett was of opinion that nothing would be done. He was right; indeed, in the run up to the election of a new board of guardians during the spring of 1839 there was much discussion in the town about voting only for those who opposed the new workhouse. In the event, the Tories, who opposed the new workhouse scheme, enjoyed a landslide victory - a rare success in any type of election in nineteenth-century Nottingham and an indication of the deeply held views on the workhouse issue. Felkin, and others thought to favour the new workhouse, were swept from office. ${ }^{69}$

The new board took a rather different approach to the workhouse question. In their view paupers and ratepayers were alike worse off under the new system, and they recommended splitting the union into two with St Mary's as a single union and St Peter's and St Nicholas's as a separate union using the

\footnotetext{
65 NR 30 March, 29 June 1838; TNA MH12/9444, Gulson to PLC, 16 Sept 1838

66 TNA MH12/9445, Richard Hall to PLC, 29 Dec 1838. By 'classification' he was implying the separation of the sexes, families, etc., as required by the 1834 legislation.

67 TNA MH12/9445, Barnett to PLC, 14, 25 Jan 1839; NR 25 Jan 1839

68 NR 18 Jan 1839

69 NR 8 Feb, 29 March 1839; TNA MH12/9445, Barnett to PLC, 4 Feb 1839. Felkin had been heavily involved with the workhouse since the Union was established, acting as a visiting guardian and regularly conducting nonconformist services on a Sunday. After this defeat he took no further part in the affairs of the Poor Law Union: S.D. Chapman, 'William Felkin, 1795-1874' (University of Nottingham, M.A. thesis, 1960), 220-3.
} 
old St Nicholas's workhouse. From the perspective of the ratepayers this was a logical move. Within unions until 1865 each parish paid for the upkeep of its own poor, and made a contribution to the overall running costs of the union. Since the great majority of Nottingham paupers lived in St Mary's parish, the costs were disproportionate. In 1837 poor law expenditure in St Mary's was $£ 6,929$, but the other two parishes together paid $f 1,649$. The guardians could argue that by dealing with their own poor the two smaller parishes would relieve pressure on the union workhouse, and that new accommodation was not needed. The Poor Law Commissioners rejected the suggestion, but with a board of guardians opposed to any unnecessary expense the workhouse issue slipped out of sight. ${ }^{70}$ According to the Review the new board took a more liberal view of out relief than its predecessors which, considering it was dominated by Tories, was no surprise. ${ }^{71}$

The workhouse question might have disappeared altogether had it not been for a depression in the silk glove branch of the hosiery trade during the winter of 1839-40. On 6 November Barnett reported that the unemployed were 'beginning this afternoon to parade the streets'. Two weeks later a deputation estimated at 1,500 people called on the mayor to provide work, and towards the end of the month numbers applying for relief began to rise. The Poor Law Commissioners accepted a request from the (Tory) board of guardians to allow outdoor relief to be paid. ${ }^{72}$

On 6 December 1839 the mayor, William Roworth, called a town meeting at which it was agreed to raise a subscription towards relief of the poor, and to try to find work for the unemployed. Already the situation was becoming uncomfortable as groups of unemployed men began 'begging in numbers in the principal streets of the town'. People were stopped in the street, and shopkeepers 'beset by gangs of these persons bearing flags, from whom they almost demand money'. The Nottingham Journal reported that 'large numbers of men assemble after dark in the evening and go to the bakers' shops in the town demanding bread, and have so much the air of intimidation about them as to

\footnotetext{
70 NR 24, 31 May, 21 June, 19 July, 23 August 1839; TNA MH12/9445, Barnett to PLC, 8, 19 June 1839, Richard Hall to PLC, 15 June 1839

71 NR 25 Oct 1839

72 NR 18 Oct, 29 Nov 1839; TAN MH12/9445 Barnett to PLC, 6, 26 Nov 1839; Edward Senior to PLC, 21 Nov 1839
} 
succeed in most cases in obtaining it in large amounts. ${ }^{73}$

More than 500 able-bodied men were set to work on Mapperley Plains. The men involved objected: 'we, the unemployed operatives in Nottingham, having been chiefly used to sedentary employments in warm workshops are totally unfitted to face the wintry blast on Mapperley Hills, or to perform any useful labour thereon, without endangering our health, which is generally speaking rendered delicate by the nature of our usual avocations'. Younger men, refused outdoor relief or work, wandered the town in gangs forcing shopkeepers to give them food. The board began to dispense outdoor relief. ${ }^{74}$

The depression through the winter of 1839-40 was limited to one branch of the hosiery trade. It proved rather less serious than the events of 1836-8, but the levels of outdoor relief paid were at least in part responsible for the election in March 1840 of a new board of guardians dominated by Whigs. The new board took a straightforward attitude: the new Poor Law could not be properly implemented when the workhouse was too small to accommodate all the able bodied applying for relief. In mid-June they debated at length the question of a new workhouse. Edward Senior, an assistant commissioner, told the guardians that 'Nottingham workhouse was the most miserable building he had ever seen'. The meeting voted 11 to 6 in favour of a new workhouse. ${ }^{75}$

This was, inevitably, a contentious decision, and the mayor, William Roworth, called a town meeting on 16 July 1840 to discuss the matter. A Whig in politics, and formerly a supporter of the 1834 Poor Law, Roworth changed his mind on becoming directly involved in meeting the needs of the poor: 'I was ignorant of its oppressive nature towards the deserving poor, until my situation as chief magistrate, during a time of great scarcity of labour, brought its effects more immediately before me'. He turned into an ardent advocate for continuing outdoor relief, because he believed that withholding it in Nottingham had 'produced the greatest distress among the industrious poor'. Roworth produced a roll call of 'neglected cases of extreme distress and destitution'. ${ }^{76}$ In his view the short-term poor, thrown out of work by trade depressions, should be relieved via out relief: the answer to their problems was not to be found in building a larger

\footnotetext{
73 N[ottingham] J[ournal] 13 December 1839; TNA MH12/9445, Barnett to PLC, 3 Dec 1839, report by Edward Senior, 10 Dec 1839

74 NR 29 Nov, 13 Dec 1839; N.C. Edsall, The Anti-Poor Law Movement, 1834-44 (1971), 201-2

75 TNA MH12/9446, John Brewster to PLC, 1 Feb 1842; NR 26 June 1840

76 Roworth, Observations, 3, 41, 43
} 
workhouse.

The town meeting was a stormy affair as a result of which the proposal was condemned, partly on the grounds of cost and partly because the larger the workhouse the less likely it was that the Poor Law Commissioners would sanction outdoor relief should a further crisis occur. ${ }^{77}$ The guardians were not easily discouraged, and over the next two years the workhouse issue dominated local politics, flowed over into Parliamentary electoral contests, and produced a minor pamphlet war. ${ }^{78}$

The first problem faced by the guardians was to find a site for the proposed new workhouse. The shortage of building land in Nottingham before the enclosure act of 1845 had been a discouragement to Barnett in 1837, and the corporation was reluctant to supply a site from its own property holdings. ${ }^{79}$ Since no land was available within the town boundary the guardians negotiated for a ten-acre site on Sherwood Rise from the Earl of Chesterfield. The land was in the parish of Radford, outside the town boundaries and within the Radford, Lenton and Sneinton union. The Poor Law Commissioners had no objections but the guardians were deeply divided on the advisability of building beyond the town boundaries. ${ }^{80}$ When news of the plan leaked out Roworth called a further public meeting on 24 August 1840. It was another tempestuous affair, as a result of which a committee was appointed to investigate the possibility of legal action against the guardians. Undeterred, the following day, 25 August, the guardians agreed to go ahead with the purchase of land from Lord Chesterfield, and to budget $£ 12,000$ for a new workhouse to accommodate 1,000 paupers. ${ }^{81}$ They then sought to nip opposition in the bud by contracting builders to begin laying the foundations of the new workhouse immediately. ${ }^{82}$

\footnotetext{
77 Roworth, Observations, 7-19; NR 17 July 1840

78 Facts and Observations; Facts Submitted to the Consideration of the Rate Payers of Nottingham in Justification of the Erection of an New Workhouse (1840); More Facts and Observations relative to The New Workhouse (Nottingham, 1840)

79 TNA HO 44/36, 205-6, William Vickers to the Home Office, 22 May 1840, asking for help to acquire land within the borough boundaries.

80 TNA MH12/9444, Barnett to PLC, 29 Dec 1837; MH12/9445, William Vickers to PLC, 10 August 1840, and their reply, 12 August 1840; NR 21 August 1840

81 Roworth, Observations, 19-38; TNA MH12/9445, Barnett to PLC, 7 July, 25 August 1840, and to Chadwick, 22 July 1840, Rev. W.J. Butler to PLC, 28 August 1840

82 TNA MH12/9446, John Brewster to PLC, 1 Feb 1842; NR 11 Sept 1840. The importance of speed may have led to a more costly design than was strictly necessary: Edsall, Anti-Poor Law Movement, 203
} 
This was deeply unpopular in the town, and on 18 September the corporation called a special meeting at which it went through the motions of condemning the guardians for proposing to build a workhouse beyond the borders of Nottingham. At the same time it agreed to limit the damage by letting to the guardians a plot of land at the rear of the existing workhouse between York and Huntingdon Streets. This would enable them to build the new workhouse adjacent to the old building. ${ }^{83}$ The guardians, who had agreed only by a narrow majority to go ahead with building on the Sherwood Rise site, immediately accepted the offer and stopped work on the foundations. It was too late to cancel the land transaction, and after some discussion about using it for a union school it was eventually sold the following spring. ${ }^{84}$

This was far from being the end of the matter as opponents tried every possible means of stopping work on the new workhouse. Roworth, together with dissident guardians and ratepayers, drew up a petition to the Treasury asking that any loans requested by the Poor Law Commissioners for the purpose of building the new workhouse should be refused. ${ }^{85}$ Within the town questions were raised as to the validity of some of the elections to the Board, and Barnett was removed from the office of vestry clerk to St Mary's, a post he had held for twenty-one years. At the municipal elections in November 1840 contests were held in many wards, focussing primarily on the workhouse issue, and the Conservatives captured four seats from the Whigs. John Hicklin, editor of the Journal, was among the successful candidates. ${ }^{86}$

The strength of feeling in the town over the workhouse issue made it obvious that the Tories might expect to regain control of the board of guardians the following spring. Completing the workhouse before that time became a key target. The assistant commissioner was already worried in August 1840 that it could not be done, and work was delayed during the winter by adverse weather. By January 1841 it was clear that the new workhouse would not be finished before the board of guardians came up for re-election. Edward Senior asked the Poor Law Commissioners to approve the election being set for the last possible date. ${ }^{87}$ In March, in a final attempt to placate opponents of the scheme, they

${ }_{83}$ R[ecords of the] B[orough of] N[ottingham] IX, 27; NAO, DD.TS 6/4/3/1-34, William Stretton's Notes; TNA MH12/9445, Barnett to PLC 19 Sept 1842; NR 8 Sept 1840; Roworth, Observations, 40-1

84 TNA MH12/9445, Senior to PLC, 25 Sept, 2 Oct 1840

85 TNA MH12/9445, petition, 19 Oct 1840

86 NR 16, 23 October, 6, 13 Nov 1840

87 TNA MH12/9445, Senior to PLC, 26 August 1840, 23 January 1841; Diary of William Carter Brown (private 
were invited to apply to the guardians for cards of invitation to visit the new building. ${ }^{88}$ William Vickers, who had chaired the Board of Guardians for the past year, issued an apology on 30 March 1841 . The guardians, he suggested, had looked carefully into the problem and had concluded 'that the best possible service they could render to the Town, and their imperative duty, were to procure the erection of a new Workhouse ... the primary objects contemplated were the proper classification of its inmates and the moral and industrial training of the orphan and deserted children ... the promotion of the comfort of the aged and infirm', and the care of those who needed support. ${ }^{89}$

When the election was held early in April 1841 no fewer than eighty-seven candidates stood for the twenty-four seats. The result was a rout. Only two members of the previous board were returned, and the Tories swept aside the Whigs. The Review estimated that the new Board consisted of seventeen Tories and seven Radicals. ${ }^{90}$ In addition, the contest coincided with a parliamentary by election. Chartists and radicals alike united behind the Tory candidate, John Walter, editor of The Times. The newspaper was a formidable and consistent critic of the 1834 legislation. ${ }^{91}$ Walter, proposed by Roworth, was returned. The winter of 1840-1 had seen the rout of the Whig-Liberals on the board of guardians, the loss of seats to the Tories in municipal elections, and the return of a Tory MP for the first time since 1807. The workhouse issue was a critical issue in all of these cases. ${ }^{92}$

VII

The new Board of Guardians promptly stopped all building work and appointed a committee to investigate the financial affairs of their predecessors and the likely cost of completing the new workhouse. ${ }^{93} \mathrm{At}$ the same time the Board served notice to the Poor Law Commissioners that the effective co-operation which had existed since 1836 was at an end. Nottingham had been the model union; now, just as the commissioners were attempting to complete

\footnotetext{
hands), 18, 21 Jan 1841. Brown was a (Whig) guardian who kept a diary January-March 1841

88 NR 19 March 1841

89 W. Vickers, An Address to the Inhabitants of Nottingham by the Retiring Board of Guardians (Nottingham, 1841)

90 NR 9 April 1841

91 M.E. Rose, 'The Anti-Poor Law Agitation', in J.T. Ward, ed., Popular Movements, c.1830-1850 (1970), 79.

92 Fraser, Urban Politics, 76-8. In the general election later in the year two Liberals were returned and Walter was unseated, but when one of the Liberals resigned in 1842 Walter was returned at the by election.

93 NR 16, 23 April 1841
} 
the union system nationwide, it was in disarray. ${ }^{94}$

When the books were inspected it became clear that the workhouse project was well over budget. Altogether $£ 12,938$ had been spent - the estimate was $f 12,000$ - and the workhouse was still incomplete. ${ }^{95}$ By mid-June the committee had worked out that the cost of completing the workhouse would be $£ 7,153$, exclusive of fixtures. According to assistant commissioner Edward Senior this was 'perfectly absurd, as the cost will not I am well assured, exceed one third of the estimate. ${ }^{96} \mathrm{He}$ noted, when he visited the workhouse in August 1841, that it would take only a few weeks to complete the building and it was beginning to seem ridiculous to leave it empty and unused while facilities in the old workhouse were stretched. A proposal from the union medical officer that the children should be moved into the new workhouse was rejected, although the guardians did agree to move the children's school to the new building. ${ }^{97}$

The crunch was likely to come during another depression in the textile trades, and to the discomfort of the Tories this arrived in the autumn of 1841. By late November 880 people were in workhouse accommodation, and a public subscription was opened for the relief of poverty by providing bread and soup. A delegation led by the mayor sought permission from the guardians to use the kitchens in the new workhouse as a soup kitchen. ${ }^{98}$ The largely Tory guardians preferred to consider increasing out relief, but by early December when over 900 people were in workhouse accommodation they inevitably had to discuss whether or not to start using completed parts of the new building. Edward Senior attended a meeting of the board 'to impress on the Board the immediate necessity of occupying the new house'. Mr Stanger, the medical officer, stressed the poor conditions in the workhouse with seven or eight children sharing a bed, and Senior launched an impassioned appeal for the guardians to act quickly. He complained that he had visited hundreds of workhouses and 'he was never over one so bad as that they were now met in, it was horrible to conceive'. He urged the guardians to make use of the new facilities, and warned that in the event of epidemic the Poor Law Commissioners would ask for an enquiry, and then 'what would be said of a Board of Guardians allowing fever to rage in one house when they had another ready built within a few yards suited in every capacity to all the

\footnotetext{
94 Edsall, Anti-Poor Law Movement, 204

95 TNA MH12/9445, Barnett to PLC, 20 April 1841, Senior to PLC, 16 May 1841, Brewster to PLC, ? May 1841

96 NR 25 June 1841; TNA MH12/9445, Senior to PLC, 25 June 1841

97 TNA MH12/9445 Senior to PLC, 6 August 1841, 24 Sept 1841; NR 24 Sept, 1, 8, 15, 22, 29 Oct, 12 Nov 1841

98 NR 26 Nov, 3, 10 Dec 1841; TNA MH12/9445, Barnett to PLC, 4 Dec 1841
} 
wants of the parish'. Nor did he expect the commissioners to sanction the movement of paupers into St Nicholas's workhouse, which had been in use as a barracks, with 'so fine a new one built and ready for occupying'. ${ }^{99}$

Senior's advice was ignored. The guardians turned to out-relief. Numbers in the house declined from 913 to 734 within a week and the guardians resolved to reduce numbers even further. In doing so they were defending the principles on which they had been elected earlier in the year, but violating the rules of the new Poor Law. When the Poor Law Commissioners objected, the guardians ignored them. This was a risky strategy, because when Robert Porter, six months old, died in the workhouse the coroner's inquest reported that a contributory factor was the number of children living in rooms 'not adapted to the number of persons required to live and sleep therein'. The medical officers were then requested to make an enquiry into the state of the workhouse. They reported that 'the accommodation afforded by the present house is utterly inadequate to the large number of persons confined in its walls'. ${ }^{100}$

This was all the incentive needed by the Poor Law Commissioners to try to regain the initiative in Nottingham. It may not have been the epidemic imagined by Senior, but this was the excuse for an enquiry. On 17 December 1841 the commissioners appointed a Harley Street doctor, Henry Hancock, to draw up a report for them on the state of the Nottingham workhouse. Hancock's commission was, in effect, to condemn the existing workhouse and force the guardians to open the new one. ${ }^{101}$ The guardians responded by extending out relief: Barnett reported that they were 'clearing out as we might do if pestilence were actually raging'. ${ }^{102}$ Other inmates, particularly boys, were removed to the old St Nicholas' workhouse. This was in defiance of the advice offered to the guardians by Edward Senior only three weeks earlier, and a clear indication of the state to which relations between guardians and commissioners had sunk. Finally, the guardians threatened to dismiss George Stanger, one of the union medical officers who had concurred with the coroner's opinion that conditions in the workhouse were a contributory cause of the death of Robert Porter and

\footnotetext{
99 Although these quotations are taken from the Review which was not sympathetic to the mainly Tory guardians at this date we may assume that Senior was correctly quoted. However, Church, Economic and Social Change, 120 mistakenly suggests that Nassau Senior, one of the Poor Law Commissioners was at this meeting, and threatened an enquiry if the guardians did not mend their ways. This is a misreading of the Review, and may explain why the guardians were willing to ignore the advice offered.

100 TNA MH12/9445 Barnett to PLC, 4, 14 Dec 1841; NR 10, 17 Dec 1841

101 TNA MH12/9445, PLC to H. Hancock, 17 Dec 1841; Senior to PLC, 18 Dec 1841

102 TNA MH12/9445 Barnett to PLC, 16 Dec 1841
} 
several other children. ${ }^{103}$

Henry Hancock inspected the workhouse on 4 January 1842, and produced a straightforward report. He found it to be 'a very irregular pile of building'. The male sleeping quarters were 'dull, close, and badly ventilated', with one bedroom 'immediately over the common privy and urinals'. Urgent steps were needed to 'ameliorate the conditions of the inmates of the Nottingham workhouse [which are] prejudicial to health, particularly that of the children'. Only the diet - 'good and ample' - escaped the general censure. None of these comments would have moved the guardians, despite the emotive language. What put them in real difficulty was his decision to set the maximum number of inmates of St Mary's at 240 and St Nicholas's at 90. Since they were currently housing 692 in St Mary's and 90 in St Nicholas's, and since the inspector had noted that the old St Peter's workhouse was 'a very small building ... at present occupied by a timber merchant ... quite unfit for a workhouse', the battle of wills was about to take a further twist. ${ }^{104}$

The Poor Law Commissioners told Barnett on 14 January 1842 that:

The remedy therefore for all the difficulties is now as before in the hands of the Guardians themselves. They have hitherto detained a large number of paupers in an impure atmosphere and crowded apartments, instead of giving them the advantages which were at any moment available of pure air, well ventilated rooms and sufficient exercise, and the commissioners can no longer delay those measures which their public duty requires them to adopt. ${ }^{105}$

The guardians were unmoved. John Brewster, their chairman, sent a long and detailed response to the Poor Law Commissioners on 1 February, which was particularly critical of the maximum figure of 240 in St Mary's workhouse when, as accompanying figures showed, the workhouse had regularly accommodated an average of well over 300 since the mid-1820s. Brewster's conclusion showed the full extent of the antagonism:

The present Board of Guardians since their accession to office have improved the dietary of the Union, have granted a larger amount of

\footnotetext{
103 TNA MH12/9445, Stanger to PLC, 22 Dec 1841; MH12/9446, Senior to PLC, 31 Dec 1841

104 Eighth Annual Report of the Poor Law Commissioners, 1842 (BPP XIX, 1), 117-22

105 TNA MH12/9446 PLC to Barnett, 14 Jan 1842
} 
outdoor relief than has ever been administered by any previous Board since the formation of the Union, and have modified in every possible manner the severity of those provisions of the law which press most cruelly on the unfortunate recipients of parochial relief. The Guardians will not therefore submit to any imputation on their humanity or consideration for the poor; all the evils which have been dreaded, but which are now happily averted, have been occasioned by the faulty system of poor laws which the commissioners are appointed to administer as the guardians are not left to the free exercise of their own judgment in the management of the poor....

As the Guardians have always regarded with aversion the Workhouse Test, they will be happy to further the views of the Commissioners by reducing as far as practicable and consistent the number of inmates now occupying the Union workhouse, but no consideration will induce them to occupy the new building erected as it has been, at an enormous and unnecessary expense, in defiance of the recorded opinions of their fellow townsmen, and with no other object than to enable the commissioners to carry more fully into effect those objectionable and harsh regulations which in many other Unions have caused the New Poor Law to be regarded with the most emphatic detestation. ${ }^{106}$

It was a spirited response, but the guardians' position was undermined when another child, Samuel Taylor, died in the workhouse on 4 February 1842. As in the Robert Porter case the coroner's verdict laid partial blame on living conditions in the workhouse. ${ }^{107}$

Not surprisingly, the Poor Law Commissioners responded negatively to Brewster's claims. They sent an order confirming the new limits of 240 in St Mary's and 90 in the St Nicholas' workhouse. With the hosiery trade in depression, one quarter of the town's population in receipt of some form or another of relief, and with 680 in the workhouse despite the guardians' policy of offering out relief, there was no room for manoeuvre. ${ }^{108}$ The commissioners, in a letter to the guardians, reiterated the figures of 240 and 90 and insisted that if

\footnotetext{
106 TNA MH12/9446 John Brewster, on behalf of Nottingham Board of Guardians to PLC, 1 Feb 1842

107 TNA MH12/9446, Barnett to PLC, 7 Feb 1842

108 NR 11 February 1842. Brewster and seven other guardians resigned en bloc, and three others in separate letters to the Poor Law Commissioners: NR 18 Feb 1842; TNA MH12/9446 William Gibson and William Parsons to PLC, 9 Feb 1842, John Miller to PLC, 10 Feb 1842
} 
these targets could not be met any additional paupers should be accommodated in the new workhouse. ${ }^{109}$

In the end there could be only one result given the continuing pressure of numbers. Ten guardians, including Brewster offered their resignations. ${ }^{110}$ These were not accepted but the dissident guardians do not subsequently appear to have attended meetings. George Bishop replaced Brewster as chairman. In mid-March 1842, with just three guardians present (the minimum to be quorate) at a meeting of the Board - one of whom was unseated in the next elections - it was agreed to accept the commissioners' orders as to numbers in the various buildings, and to do so by transferring the overflow into the new workhouse. Within a week 140 had been moved into the new house, leaving 258 in St Mary's and 107 in St Nicholas's. ${ }^{111}$

This was the last act of the board before the annual elections held at the end of March 1842. Seventy-nine candidates stood for the twenty-four places. Of those elected the Review commented that they were almost equally divided between the new workhouse party and the anti-workhouse party. Yet with the new workhouse effectively open the Board could hardly turn back the clock. Barnett was allowed to complete the transfer of inmates from St Mary's to the new workhouse, and building work was finished in $1843 .{ }^{112}$

The new workhouse, designed for 1,150 inmates, was built at a cost of $£ 18,459$. Furnishings cost a further $£ 434$ and corn mills - to be operated by the inmates $-\mathrm{f185}$. To help offset these sums the guardians requested leave from the commissioners to sell the three redundant workhouses. ${ }^{113}$ St Peter's was subsequently sold to the Primitive Methodists for $£ 1,205$, and St Nicholas's to a private buyer for $£ 2,600$. St Mary's went at auction to Benjamin Drewry for $£ 3,840$, although he subsequently withdrew as a result of title disputes. Part of the land was sold in 1843 to $\mathrm{Mr}$ John Wood, but the house itself remained unsold in 1853 when it was valued at $£ 4,500$. By then the net expense of building the new workhouse was $£ 10,774 .{ }^{114}$

\footnotetext{
109 NR 25 Feb 1842

110 NR 18 Feb 1842; TNA MH12/9446 William Gibson and William Parsons to PLC, 9 Feb 1842, John Miller to PLC, 10 Feb 1842

111 NR 18 March 1842. Nottingham Mercury 18, 25 March 1842

112 NR 1 April 1842; TNA MH12/9446 Barnett to PLC, 28 March 1842; W. White, History and Directory of the County of Nottinghamshire (Sheffield, 1844), 118

113 NR 20 May, 17 June 1842; TNA MH12/9446 PLC to Barnett, draft June 1842.

114 TNA MH12/7446 Barnett to PLC, 2 Nov, 8, 12 Dec 1842; MH12/7447 same to same, 21 Feb, 22 April, 11 August 1843; W. White, History and Directory of the County of Nottinghamshire (Sheffield, 1853), 68
} 
With the opening of the new workhouse the battle was effectively over. Only forty-seven people contested the 1843 guardian elections, and among those who were successful was John Brewster, who had resigned in 1842 rather than be party to opening the new workhouse. ${ }^{115}$ Twelve of those returned had served on the previous board, which was welcome continuity. Although forty-eight stood in 1844, thirteen sitting members were returned. This compared with only four in 1842, two in 1841 and four in 1840. The Board remained a party issue: the Journal commented in 1845 that 'as usual this contest, like all others which take place in Nottingham, has been made the subject of strong party exertions.' In this case the reason was the desire on the part of the Whigs to secure a majority so that they could nominate Barnett's successor as the next master of the workhouse following his resignation in $1845 .{ }^{116}$

By the time the new workhouse was opened in 1842 the worst of the trade depressions which characterized the 'hungry forties' was over, although 1,600 people were packed into the workhouse in April $1848 .{ }^{117}$ In general, the new workhouse was seldom full; the average weekly number of inmates was below 700 in most years, and in a particularly bad year such as 1857 the guardians asked the Poor Law Board (the successor body to the Poor Law Commission) to suspend the prohibition on outdoor relief and allow them to give outdoor relief to able-bodied men with two or more children. There was no repeat of the events between 1836 and 1843 in Nottingham.

\section{VIII}

The New Poor Law was an attempt to treat pauperism in a novel and rather different form, but it was based on principles honed in selected parishes, among them St Mary's Nottingham. Central to the new policy was the idea that relief depended upon entry into a well-regulated workhouse which, through both its architecture and its disciplinary regime, was to be the instrument of a

\footnotetext{
115 Brewster was not the only resigning guardian subsequently to return to the Board. Another was William Parsons, who kept a diary for much of this period although not during the crucial events of 1841-2. He had resumed scribbling in 1851 when he 'attended as one of the Visiting Committee and went through every department of the Union Poor House, a vast establishment, kept very cleanly and excellently managed under the Master Harrison.' Nottingham University, Department of Manuscripts and Special Collections, William Parsons' Diary, 6 February 1851

116 NJ 18 April 1845

117 Church, Economic and Social Change, 146
} 
moral reformation. In addition, and to stiffen the resolve of boards of guardians, powers were entrusted into the hands of a centralized Poor Law Commission. This was the theory. The problems of implementation were numerous, largely because of unwillingness at a local level to accept control from London: as early as 1838 the commissioners had been forced to concede discretion over the provision of outdoor relief to unions in Lancashire and West Yorkshire.

In Nottingham, conditions for implementing the new legislation seemed ideal. The commissioners could rely on the union officials, particularly Barnett, and on the Whig board of guardians. This was far easier than the position in towns such as Leicester and Leeds where, despite the local government successes of the Whigs after the reform of the municipal corporations in 1835, the boards of guardians remained predominantly Tory in outlook. ${ }^{118}$ An assistant poor law commissioner noted of Leeds that 'political party feeling prevails to a mischievous extent at Leeds - the parties are nearly balanced and it is scarcely possible to take any step in Leeds Township without exciting strong party feeling ${ }^{119}$ This was not initially the case in Nottingham, but it became so in the battle over the new workhouse. Sympathetic boards of guardians, elected from among the minority Tory interest in the town, could resist the Poor Law Commissioners, and pay out-relief in times of trade depression. Nottingham showed that if the legislation was to be implemented fully a new, purpose-built workhouse, was needed capable of housing all the able bodied poor in all but the most serious circumstances. But the capital costs were daunting. As early as 1834 J.D. Tweedy, assistant commissioner for the West Riding of Yorkshire, argued that outdoor relief was the best solution to the temporary problems brought about by large scale unemployment, a point he developed by reference to the cost of building a new workhouse in Sheffield and how much the debt incurred added to the annual expenditure on the poor. ${ }^{120}$

The Nottingham union had been a rigorous test for the new Poor Law in an urban-industrial setting, but it also pointed to the potential problems likely to be faced in northern England even if the worst of the anti-Poor Law agitation was over by 1842 . The more circumspect approach taken during the 1840 s by the Poor Law Commissioners towards local prejudices owed much to the troubles

\footnotetext{
118 K.M. Thompson, 'Power and Authority in Leicester, 1820-1870', (University of Nottingham, MA thesis, 1985), 69, 71

119 TNA, MH12/15225, correspondence with Leeds Poor Law Union, 24 Aug 1841; Derek Fraser, 'Areas of Urban Politics - Leeds, 1830-80', in H.J. Dyos and M. Wolff (eds), The Victorian City: Image sand Realities, II (1970), 770.

120 'Working of the Poor Laws', Sheffield Independent and Yorkshire and Derbyshire Advertiser, 5 April 1834
} 
encountered in Nottingham. ${ }^{121}$ If it was not possible to enforce the rules with the rigour anticipated in 1834 in Nottingham, it was not likely to be in the industrial towns of northern England.

For a while, supported by Barnett, the Poor Law Commissioners managed to maintain the image that the new legislation had been effectively and efficiently introduced in Nottingham, but to those in northern England awaiting visitations from assistant commissioners, events in the winter of 1836-7 helped to fan the flames of opposition and to create tensions in the months and years that followed. When, late in 1836 , the assistant commissioners turned their attention to the northern counties, the level of resistance they encountered was much greater than in the Midlands. Opposition turned into furious assault as thousands of previously peaceful working people began to appreciate the full horrors of the workhouse. Many northern authorities resisted the demand that they should build new workhouses, or have workhouses at all: Todmorden, for example, was still resisting in 1846 . Compromises had to be found in the implementation of the law in towns, ${ }^{122}$ and although the 'model' Nottingham union may have passed from public view as attention shifted into Lancashire and Yorkshire, it became embroiled in a major local political row largely centred on the use - and abuse - of the institution most feared in the north - the workhouse.

\section{Acknowledgements}

I should like to thank Dr Richard Gaunt, Dr Kate Thompson, and an anonymous reader for reading and commenting on earlier versions of this paper. I am also grateful to the late Mr Geoffrey Oldfield who put at my disposal his notes taken from Nottingham newspapers in this period.

\section{Notes on contributor}

Professor John Beckett, University of Nottingham, University Park, Nottingham, NG7 2RD, UK. Email: John.Beckett@nottingham.ac.uk

121 Edsall, The Anti-Poor Law Movement, 205

122 Edsall, Anti-Poor Law Movement, chapter III; Rose, Poor and the City, 7; Crowther, Workhouse System, 45 